\title{
Giving Substance to the Bonus Rule in Corporate Reorganizations: The Investment Value Doctrine Analogy*
}

When a relatively large corporation is insolvent, ${ }^{1}$ the only practical course of action short of liquidation ${ }^{2}$ may be for it to enter bankruptcy reorganization under Chapter $\mathrm{X}$ of the Bankruptcy Act. ${ }^{3}$ Since Chapter $X$ reorganization is a product of the Depression era, ${ }^{4}$ it is not surprising that it consists largely of doctrinal matters settled long before 1950.5 But a longstanding criticism has been energetically revived in the recent report of the Commission on the Bankruptcy Laws. ${ }^{6}$ The report charged that the Chapter $\mathrm{X}$ process consistently undercompensates junior security holders. ${ }^{T}$ The Bankruptcy Commis-

* The author wishes to thank Professor Marvin A. Chirelstein for his assistance in the formulation and preparation of this Note.

1. Insolvency has two meanings: a corporation may be insolvent in either the bankruptcy sense-assets are less than liabilities-or in the equity sense-assets are worth more than liabilities but, due to a lack of liquidity, the corporation cannot meet its debts as they mature. H. Guthmann \& H. Dougali, Corporate Financial Policy 627-28 (3d ed. 1955); G. Hirsch, BankRUPtcy 19-20 (1964).

2. H. GuthmanN \& H. Dougal, supra note 1 , at 688 :

The term liquidation is applied when the business is wound up and the assets are converted into cash or securities (as in the case of the sale of assets to another concern in return for its securities), which are distributed to the owners and creditors. Liquidation is usually the result of a financial condition which no treatment, mild or drastic, can remedy.

See generally 2 A. Dewing, The Financial Policy of Corporations 1414-16 (5th ed. 1953).

3. Bankruptcy Act $\$ \S 101-276,11$ U.S.C. $\$ \$ 501-676$ (1970).

4. Section $77 \mathrm{~B}$, the predecessor of Chapter $\mathrm{X}$, was originally regarded as emergency legislation. Hearings on the Revision of the Bankruptcy Act Before the House Comm. on the Judiciary, 75th Cong., 1st Sess. 5 (1937).

5. Case v. Los Angeles Lumber Prods. Co., 308 U.S. 106 (1939); Consolidated Rock Prods. Co. v. DuBois, 312 U.S. 510 (1941). See generally Brudney, The Investment-Value Doctrine and Corporate Readjustments, 72 HARV. L. REV. 645, 648 (1959).

6. Commission on the Bankruptcy Laws of the United States, Report, H.R. Doc. No. 93-137, 93d Cong., lst Sess., pt. 1 (1973) [hereinafter cited as REPORT]. The Commission on Bankruptcy Laws was created by the Act of July 24, 1970, Pub. L. No. 91-354, 84 Stat. 468. The charge to the Commission was to "study, analyze, evaluate, and recommend changes to the [Bankruptcy] Act... in order for such Act to reflect and adequately meet the demands of present technical, financial, and commercial activities." Id. $\$ 1(b)$. See H.R. 10792, 93d Cong., 1st Sess. (1973) (proposed bankruptcy statute). Section 7 of the proposed statute is the relevant section dealing with corporate reorganization. See generally Trost, Corporate Bankruptcy Reorganizations: For the Benefit of Creditors or Stockholders?, 21 U.C.L.A.L. REv. 540 (1973).

7. REPORT, supra note 6, at 256-58. Basically, the hierarchy of a firm's capital structure ranges from "debt" downward to "equity." W. CARY, Corporations 1177-78 (4th ed. 1969); H. Guthmann \& H. Dougald, supra note 1 , at 98 . Although there are numerous subdivisions of securities, the most important are: bonds (debts secured by liens on certain properties); debentures (debts secured only by the general credit of the corporation); preferred stock (equity with a prior right to dividends and to assets); and common stock (equity with a residual claim to earnings and to assets). See id. at 83, 98-99, 112, 138-39. That order also represents their ranking from more "senior" to more "junior" securities. In this Note, the term "qualitative" refers to this hierarchy of securities in the firm's capital structure. Common stock, therefore, may be said to be qualitatively inferior to bonds. See, e.g., Consolidated Rock Prods. Co. v. DuBois, 312 U.S. 510, 528-29 (1941). 
sion's analysis has itself encountered sharp criticism, 8 but its work does reflect dissatisfaction with the postulates and practices of Chapter $\mathrm{X}$. Important among the postulates is the "bonus rule," which requires special additional compensation for any senior creditors of the defaulting firm who are paid off in securities of the reorganized firm that are of lower rank in the capital structure than the senior creditors' original securities. ${ }^{\circ}$ Recent criticism of the theoretical consistency of the bonus rule, moreover, lends apparent support to the Commission's criticisms that senior security holders are overcompensated. ${ }^{10}$ The bonus rule, consequently, is a natural target for reform proposals designed to aid junior security interests.

This Note argues that the bonus rule is essential in practice and is consistent with corporate reorganization theory. It contends as well that courts could replace the somewhat unpredictable calculation of the proper bonus that now prevails with a system promising greater precision. They could do so by selectively incorporating the principles of the investment value doctrine, the doctrine used in carrying out the terms of Section 11 of the Public Utility Holding Company Act of 1935.11

\section{Absolute Priority in Bankruptcy Reorganization under Chapter X}

Chapter $\mathrm{X}$ is designed to be used when a "corporation is insolvent or unable to pay its debts as they mature."12 The consequence of such a condition is the immediate maturing of the claims of the defaulted senior security holders; according to the terms of the typical investment contract, it would be an appropriate time for foreclosure and, probably, liquidation of the enterprise. ${ }^{13}$ A forced liquidation, how-

8. Brudney, The Bankruptcy Commission's Proposed "Modifications" of the Absolute Priority Rule, 48 AM. BANkr. L.J. 305 (1974) [hereinafter cited as Brudney, Bankruptcy Commission]. See Note, The Proposed Bankruptcy Act: Changes in the Absolute Priority Rule for Corporate Reorganizations, 87 HARv. L. REv. 1786 (1974).

9. See Consolidated Rock Prods. Co. v. DuBois, 312 U.S. 510, 528-29 (1941); p. 940 infra.

10. Blum, Corporate Reorganization Doctrine as Recently Applied by the Securities and Exchange Commission, 40 U. CHI. L. REv. 96, 110 (1972) [hereinafter cited as Blum, Corporate Reorganization Doclrine].

11. 15 U.S.C. $\$ 79 k$ (1970). See generally SEC v. Central-Illinois Sec. Corp., 338 U.S. 96, 131 (1949); 25 SEC ANN. REP. XXV-XXYI (1959) (foreword); Brudney, supra note 5.

12. Bankruptcy Act $\$ 130(1)$, 11 U.S.C. $\$ 530(1)(1970)$. Although framed in terms of Chapter X, this Note is equally applicable to Section 77 of the Bankruptcy Act, II U.S.C. $\$ 205(1970)$, dealing with the reorganization of railroads, since the standards for the valuation and payment of claims are used in Section 77 as in Chapter X. Section 77 diverges largely in the scope of authority given to the Interstate Commerce Commission over the plan of reorganization.

13. The investment contract, in the case of bonds or debentures, is called the "indenture." It represents the agreement between the debtor corporation, the trustee of the issuer, and the bondholders (or the debentureholders). H. GuthmanN \& H. Dougall, supra note 1 , at $110-11$. 
ever, would ignore the possibility that the firm, although insolvent, may be worth more as a going-concern than it is as an aggregate of salable assets. To avoid such an economically undesirable result, Chapter $\mathrm{X}$ provides a mechanism for overriding the terms of the security holders' investment contracts, to enable the corporation to be reorganized when the going-concern value of the enterprise is greater than its liquidation value. ${ }^{14}$

\section{A. Valuation of Claims}

The Chapter $\mathrm{X}$ process begins with the valuation of the claims of the various security holders. Theoretically there are a number of possible standards for measuring claims, such as liquidation rights or investment values, ${ }^{15}$ but it has been clear since Case $v$. Los Angeles

Under the Trust Indenture Act of 1939, 15 U.S.C. $\$ \$$ 77aaa-77bbbb (1970), the opportunity for the postponement of principal or interest past due dates is severely restricted: The indenture to be qualified shall provide that, notwithstanding any other provision thereof, the right of any holder of any indenture security to receive payment of the principal of and interest on such indenture security, on or after the respective due dates... shall not be impaired or affected without the consent of such holder, except as to a postponement of an interest payment [for not more than three years, if authorized by the holders of not less than 75 per centum in principal amount of the outstanding indenture securities].

Id. $\$ \S 77 \mathrm{ppp}(\mathrm{b})$.

14. See Blum, The Law and Language of Corporate Reorganizations, 17 U. CHI. L. REv. 565, 566 (1950) [hereinafter cited as Blum, Law and Language]: "One [of the main principles that constitutes the framework for the current system of reorganization] is that the assets of a distressed business are not to be disposed of until there has been a reasonable opportunity to determine what disposition will be most advantageous. See, e.g., In re Portland Elec. Power Co., 162 F.2d 618, 621-22 (9th Cir.), cert. denied, 332 U.S. 837 (1947); North American Car Corp. v. Peerless Weighing \& Vending Mach. Corp., 143 F.2d 938, 940 (2d Cir. 1944); Atlas Pipeline Corp., 9 S.E.C. 416 (1941); Blum \& Kaplan, The Absolute Priority Doctrine in Corporate Reorganizations, 41 U. CHI. L. REV. 651, 660 (1974); Ferber, Blasberg \& Katz, Conflicts of Interest in Reorganization Proceedings Under the Public Utility Holding Company Act of 1935 and Chapter $\mathrm{X}$ of the Bankruptcy Act, 28 Geo. WAsh. L. Rev. 319, 326 (1959); Guthmann, Absolute Priority in Reorganizations: Some Defects in a Supreme Court Doctrine, 45 Colum. L. Rev. 739, 745 (1945).

15. The investment value doctrine was developed as the method of implementing Section 11 of the Public Utility Holding Company Act of 1935 , 15 U.S.C. $\$ 79 k(1970)$. See SEC v. Central-Illinois Sec. Corp., 338 U.S. 96, 131 (1949); Brudncy, supra note 5, at 64651. It calls for claims to be measured by their going-concern values rather than by the formal requirements of the security holders' contracts or by some other norm. Brudney, supra note 5, at 649; Electric Bond \& Share Co., 30 S.E.C. 155, 170 (1949). Numerous suggestions have been made that the investment value doctrine should be imported wholesale into Chapter $X$, as a replacement for claims measurement on the basis of liquidation rights. Billyou, Priority Rights of Security Holders in Bankruptcy Reorganizations: New Directions, 67 HARv. L. REv. 553 (1954) [hereinafter cited as Billyou, New Directions]; Billyou, "New Directions": A Further Comment, 67 HARv. L. REv. 1379 (1954); Guthmann, supra note 14; Comment, Allocation of Securities in Corporate Reorganizations: Claims Measturement Through Investment Value Analysis, 61 YaLE L.J. 656 (1952). These proposals were based on the perception that the policies underlying Chapter $\mathbf{X}$ and Section 11 , as reflected in many cases, were fundamentally similar. See e.g., Billyou, New Directions, supra, at 583.85; Comment, supra, at 683-85. Those suggestions met strong opposition. Blum, The "New Directions" for Priority Rights in Bankruptcy Reorganizations, 67 HaRv. L. REv. 1367 (1954); Brudney, supra note 5. The most cogent response argued that the use of going-concern values (inevitably diminished in the situation of a company that had failed) to measure the size of the claim would undermine the expectations of the 
Lumber Products Co. ${ }^{16}$ that claims are to be measured by their liquidation rights. ${ }^{17}$ Case established, as well, what is now referred to as the absolute priority rule: ${ }^{18}$ The Supreme Court, interpreting the statutory requirement of a "fair and equitable" settlement of claims, ${ }^{19}$ held that junior security holders are not entitled to participate unless and until the claims of the more senior security holders have been satisfied in full. In other words, the classes are to participate to the same extent they would have in an actual liquidation..$^{20}$

senior security holders, who, in taking senior securities, justifiably expected the risk of economic distress to be visited first on the juniors. Brudney, supra note 5, at 664-65, 671; Blum \& Kaplan, supra note 14 , at 663 . The use of investment value analysis, moreover, was thought to be inconsistent with the absolute priority rule in Chapter $\mathrm{X}$, Blum, Full Priority and Full Compensation in Corporate Reorganization-A Reappraisal, $25 \mathrm{U}$. CHI. L. REv. 417, 426 (1958) [hereinafter cited as Blum, Full Priority]; Brudney, supra note 5, at 686-87, as well as with Chapter X's historical status as a substitute for liquidation. This analysis has been accepted as determinative of the issue. See, e.g., Blum \& Kaplan, supra note 14, at 659; Note, supra note 8, at 1799 n.78. Thus the investment value doctrine has lain dormant in the recent past.

16. 308 U.S. 106 (1939); cf. Northern Pac. Ry. v. Boyd, 228 U.S. 482 (1913).

17. Taylor v. Standard Gas \& Elec. Co., 306 U.S. 307 (1939); 10 SEC ANN. REP. 150 (1944); Blum, The "New Directions" for Priority Rights in Bankruptcy Reorganizations, supra note 15, at 1371; Blum, Full Priority, supra note 15, at 426.

"Liquidation rights" refers to the amount, specified in the security indenture, that a security of a defined class shall receive upon the liquidation of the enterprise. As such, it is distinct from the "going-concern right" of the security-the amount it is entitled to get from a continuing corporation-and from the "going-concern value," that is, the market price, Blum \& Kaplan, supra note 14, at 659 , of the security. See, e.g., Brudney, supra note 5 , at $668 \cdot 69$.

18. The "absolute priority rule" was first named in Bonbright \& Bergerman, Two Rival Theories of Priority Rights of Security Holders in a Corporate Reorganization, 28 Col.um. L. Rev. 127 (1928). See Case v. Los Angeles Lumber Prods. Co., 308 U.S. 106, 11519 (1939). It has since been applied consistently. See Consolidated Rock Prods. Co. v: DuBois, 312 U.S. 510, 520-21 (1941); Marine Harbor Properties, Inc. v. Manufacturers Trust Co., 317 U.S. 78, 86-87 (1942); SEC v. American Trailer Rentals Co., 379 U.S. 594, 611 (1965); Protective Comm. for Indep. Stockholders of TMT Trailer Ferry, Inc. v. Anderson, 390 U.S. 414, 441 (1968); United States v. Key, 397 U.S. 322, 327, 333 (1970); Baker v. Gold Seal Liquors, Inc., 417 U.S. 467, 473 \& n.11 (1974); Rostow \& Cutler, Competing Systems of Corporate Reorganizations: Chapters $X$ and $X I$ of the Bankruptcy ACt, 48 YALE L.J. 1394, 1347-50 (1939); Brudncy, supra note 5, at 647.

19. Bankruptcy Act $\$ 216,11$ U.S.C. $\$ 616(1970)$.

20. The merits of the absolute priority rule have been extensively debated. See, e.g., Bonbright \& Bergerman, supra note 18; Guthmann, supra note 14 (early articles arguing support for the so-called "relative priority rule"). For many of the more reflective materials, sec 2 J. Bonbright, The Valuation of Property 864-70 (1937); 2 A. Dewing, supra note 2, at 1299-1304; cf. Foster, Conflicting Ideals for Reorganization, 44 YALE L.J. 923, 960 (1935). For a brief description of the difference between the absolute priority rule and its most frequently discussed alternative, the relative priority rule, see $6 \AA$ Collier on BankRuprCY 11.06, at 623-25 (14th ed. 1972). See generally Polatsek, The Wreck of the Old 77, 34 CORN. L.O. 532, 533 (1949).

Curiously, Justice Douglas, in Baker v. Gold Seal Liquors, Inc., 417 U.S. 467 (1974), mentions that "[r]eorganization under $\$ 77$ aims at a continuation of the old business under a new capital structure that respects the relative priorities of the various claimants." Id. at 47111.3 (emphasis added). The opinion is clear, however, that Justice Douglas did not mean, by that phrasc, to adopt a relative priority rulc over the absolute priority rule; incleed, he reaffirms the latter, see $i d$. at $473 \&$ n.ll.

$A$ fairly broad consensus, supporting the reasoning in Case and justifying the absolute priority rule, has emerged. See, e.g., Blum, Full Priority, supra note 15, at 419; Friendly, Some Comments on the Corporate Reorganizations Act, 48 HARv. L. REv. 39, 77 (1934); Friendly \& Tondel, The Relative Treatment of Securities in Railroad Reorganizations Under Section 77, 7 Law \& Contemp. Prob. 420, 422-25 (1940); Note, Absolute Priority 


\section{B. Payment of Claims}

Although the practice of valuing claims by the absolute priority rule is well established, the valuation of claims is only the first of a court's tasks in reorganization. Claims not only must be measured, they also must be "paid." 21 Payment involves uncertainty when applied to an enterprise that is to be continued rather than liquidated, since the claims are to be paid not with cash or with assets but with the reorganized firm's securities, the value of which will depend on the value of the reorganized company as a going-concern..$^{22}$ The court must determine this going-concern value. An obvious source for the figure is the "market value" of the company-that is, the value of the company as computed from the prices that the company's currently outstanding securities command in the securities markets. Instead of market value, however, courts use a judge-made figure which is termed the enterprise's "reorganization value." 23 This has come to mean a valuation based on the capitalization, at an appropriate rate, of prospective earnings. ${ }^{24}$ This valuation, as well as its component

Under Chapter X-A Rule of Law or a Familiar Quotation?, 52 Colum. L. Rev. 900, 90203 (1952). See generally, Brudncy, supra note 5, at 677-82; Gerdes, Supreme Court Ruling on Reorganization, N.Y. Herald Tribune, Mar. 9, 1941, $\$ 2$, at 11 , col. 3, reprinted in E. Dodd \& D. Billyou, Corporate Reorganization $72-73$ (1950).

The consensus builds on a recognition that the reasons for preferring reorganization to liquidation do not provide a justification for the substitution of another rule and the concomitant visitation of the impact of the reorganization on those who, contractually, have priority in a situation where default has occurred. See Brudney, supra note 5, at 677, 681; V. Brudney \& M. Chirelstein, Corporate Finance 120 n.p (1972).

Even the Bankruptcy Commission ostensibly subscribes to the consensus in favor of the absolute priority rule. See REPORT, supra note 6, at 258; Rochelle \& Balzersen, Recommendations for Amendments to Chapter X, 46 AM. BANKR, L.J. 93, 99 (1972) (Rochelle was a member of the Bankruptcy Commission). See generally Brudney, Bankruptcy Commission, supra note 8, at 307-08. But many, with justification, have charged that the Commission's proposals would in fact vitiate the rule. Id. at $320-23,332-33,340$; Blum \& Kaplan, supra note 14, at 672-73. Note, supra note 8 , at 1811-16.

21. Billyou, New Directions, supra note 15, at 566.68; $c f$. T. FinletTer, ThE LAw of BANKRUPtcy REORGANIZATION 438-39 (1939). The absolute priority rule is of lesser aid in defining what is full payment, for it is a standard which speaks most directly to the phenomenon of meastrement, stated in a sum certain, and not to the problem of determining what will constitute appropriate payment. See, e.g., Friendly \& Tondel, supra note 20, at 423 .

22. 6A Collier on BANkrumtcy (11.05, at 594-95 (14th ed. 1972). See, e.g., Northern Pac. Ry. v. Boyd, 228 U.S. 482, 508 (1913); P.R. Walsh Tie \& Timber Co. v. Missouri Pac. Ry., 280 F. 38, 44 (8th Cir.), cert. denied, 260 U.S. 743 (1922); In re General Stores Corp., 150 F.Supp. 868, 871 (S.D.N.Y. 1957), aff'd on other grounds sub nom. Ruskin v. Griffiths, 250 F.2d 875 (2d Cir. 1958); Friendly, Some Comments on the Corporate Reorganizations Act, supra note 20 , at 77 .

23. Blum, Law and Language, supra note 14, at 565; Note, supra note 20, at 904:

The importance of the valuation figure cannot be overstressed, as it determines the size of the pie to be cut up among the various classes of old security holders. It thus determines whether and to what extent junior security holders share in the new company.

24. Consolidated Rock Prods. Co. v. DuBois, 312 U.S. 510, 525-26:

Findings as to the earning capacity of an enterprise are essential to a determination of the feasibility as well as the fairness of a plan of reorganization.... It is also es- 
parts, is the ultimate responsibility of the reorganization judge, who makes his decision based on suggestions and information from the SEC, the corporation, and the creditors. ${ }^{25}$ Reorganization value is thus a theoretical construct. It may perhaps coincide with the market determination of value, but the one is not determined by nor dependent on the other. This rejection of the market ${ }^{26}$ appears in the valuation not only of the aggregate enterprise, but also of the component securities that will aggregate to the enterprise value; ${ }^{27}$ the court recognizes only the "face value"28 of the individual securities to be used in payment.

sential for satisfaction of the absolute priority rule of Case v. Los Angeles Lumber

Products Co....

It is plain that valuations for other purposes are not relevant to or helpful in a determination of that issue, except as they may indirectly bear on earning capacity. ... The criterion of earning capacity is the essential one....

See, e.g., Group of Institutional Investors v. Chicago, Mil., St.P. \& Pac. R.R., 318 U.S. 523, 540-41 (1943); Protective Comm. for Indep. Stockholders of TMT Trailer Ferry, Inc. v. Anderson, 390 U.S. 414, 441-42 (I968); Moulded Products, Inc, v. Barry, 474 F.2d 220, 225 (8th Cir.), cert. denied, 412 U.S. 940 (1973); In re Muskegon Motor Specialties, 366 F.2d 522, 525 (6th Cir. 1966); In re Associated Gas \& Elec. Co., 149 F.2d 996, 1109 (2d Cir.), cert. denied, 326 U.S. 736 (1945); In re Spectrum Arena, Inc., 340 F.Supp. 767, 778 (E.D.Pa. 1971), aff'd, 462 F.2d 156 (3d Cir..1972); In re Alabama, Tenn. \& N.R.R. Corp., 47 F. Supp. 694, 707.08 (S.D. Ala. 1942); SEC, Rerorr ON THE Study AND INVESTIGATION OF THE WORK, Activities, Personnel and Functions of Protective and Reorganization Comimtees, $\mathrm{pt}$. 8 , at $156(1940)$.

25. See, e.g., In re Quaker City Cold Storage Co., 71 F.Supp. 124 (E.D. Pa. 1947); 6A COLLIER ON BANkrumcy 911.05 , at 590-93 (14th ed. 1972); Blum, Law and Language, supra note 14, at 572-75, 577-78; King, Chapter $X$ Valuation: Principles on Application, 42 REF. J. 108, 109-10 (1968); Note, supra note 20, at 904-05, 907; Note, Bankruptcy: Corporate Reorganization: Survey of Chapter $X$ in Operation, 18 N.Y.U.L.Q. REv. 399, 464 (1941). For an examination of the selection of different valuations, compare La France Indus., 5 S.E.C. 917, 936 (1939), with In re La France Indus., CCH BANKR. L. REP. I 52,339 (E.D. Pa. Dec. 8, 1939); compare Flour Mills of America, 7 S.E.C. 1 (1940), with Flour Mills of America, 7 S.E.C. 30 (1940); compare Atlas Pipeline Corp., 9 S.E.C. 416 (1941), with In re Atlas Pipeline Corp., 39 F.Supp. 846 (W.D. La. 1941).

26. Blum, Law and Language, supra note 14, at 571-72; Blum, Full Priority, supra note 15, at 419-20; cf. Frank, Epithetical Jurisprudence and the Work of the Securities and Exchange Commission in the Administration of Chapter $X$ of the Bankruptcy Act, 18 N.Y.U.L.Q. REv. 317, 340-43 (1941); Gardner, The S.E.C. and Valuation Under Chapter X, 91 U. PA. L. REv. 440, $456-57$ (1943). Although it is sometimes asserted that the court is concerned with the long-term value of the security, it is hard to imagine that the market is not also concerned with long-term value. See W. LEWELLEN, The Cost of CAPITAL 88-93 (1969); V. BRUDNEY \& M. ChIRELSTEIN, supra note 20, at 421-22: "The [dividend capitalization model of share valuation] assumes that the present value of a share of stock is equal to the value of all future dividend payments, capitalized at a rate reflecting the market's view of the risks associated with the firm's expected income stream." Cf. Brudney, supra note 5 , at 660 .

27. Apart from the question of leverage it is definitionally true that the aggregate value of the securities outstanding should equal the enterprise value. On the question of leverage, see B. Graham, D. Dodd \& S. CotTle, Security Analysis 539-50 (4th ed. 1962). The concept of leverage-at least apart from the external tax effect-has come under cogent attack. See Modigliani \& Miller, The Cost of Capital, Corporation Finance and the Theory of Investment, 48 AM. Econ. Rev. 261 (1958) (the classic statement of the proposition that leverage is irrelevant). See generally V. BrudNeY \& M. ChiretsreIn, supra note 20, at 381-98; J. VAN HoRne, Financial. Management and Policy 212-13 (1971).

28. See Friendly \& Tondel, supra note 20, at 424; cf. Consolidated Rock Prods. Co. v. DuBois, 312 U.S. 510, 528-29 (1941); Missouri Pacific R.R., 290 I.C.C. 477, 555 (1954), plan approved, 129 F.Supp. 392 (E.D. Mo.), aff'd, 225 F.2d 761 (8th Cir. 1955), cert. denied, 350 U.S. 959 (1956); Frank, supra note 26, at 340 . Face value is usually the same as the liqui- 
It has been asserted that the court's rejection of market value stems from a perception that the market is-at least temporarily-unreliable in valuing a company that has failed. ${ }^{29}$ Professor Blum suggests, however, that such a rationale, while helpful in understanding the existing system of corporate reorganization, was not decisive in molding the system. "The prevailing pressure," he contends, "was to relieve junior corporate investors from their senior contracts which had turned out disastrously for them."30 This implied relief function for junior security holders is in fact generally fulfilled: The Chapter $\mathrm{X}$ courts consistently establish reorganization values that exceed market values, sometimes by a substantial margin. ${ }^{31}$ Because the market is not determinative in the process, reorganizations pursuant to Chapter $\mathrm{X}$ permit a deviation from the cash equivalence concept of the absolute priority rule: A senior security holder ends up with pieces of paper which cannot be exchanged on the market for the cash amount of his original,

dation value of the security: if a bond has a face value of $\$ 1,000$, it will be entitled to $\$ 1,000$ on liquidation.

Professor Blum writes: "Reorganization value is what some appraisers believe the current market value of the distressed company ought to be if the present were like the futurc they foresee. It is thus a liberalization of market price corresponding with some expert opinion about the inherent value of the enterprise." Blum, Law and Language, supra note 14 , at 578. See, e.g., id. at 572, 579-581.

29. Blum, Law and Language, supra note 14, at 567-68. A corollary to this position must be that the court assumes it is able to approximate the "true" going-concern valuc of a security more accurately than the market is able to. A considerable body of literature, however, casts doubt on the ability of a nonmarket agency-be it an investor, an investment adviser, or a court-to "out guess" the market. See V. BRudney \& M. Chirelstein, supra note 20, at 1108-23; B. Malkiel, A Random Walk Down Walc Street (1973); SEG, Institutional Investor Study Report, H.R. Doc. No. 64, 92d Cong., lst Sess., supp. vol. I, at 227-30 (1971); Cohen, The Suitability Rule and Economic Theory, 80 YALE L.J. 1604, 1614-17 (1971); Fama, Efficient Capital Markets: $A$ Review of Theory and Empirical I'ork, 25 J. FIN. 383 (1970); Sharpe, Mutual Fund Performance, 1966 J. Bus. 119; Bishop, Book Review, 83 YALE L.J. 1100, 1108-09 (1974).

30. Blum, Law and Language, supra note 14 , at 569 . Whether utilization of the market for the valuation of an enterprise in Chapter $\mathrm{X}$ was rejected because of a perception that a pessimistic market is especially unreliable in valuing corporations in default or whether it was rejected because of a desire to relieve junior corporate investors from some of the burden of bankruptcy reorganization, the implication must be that the market value will be lower than the reorganization value during the period of, and immediately after, the reorganization. See Blum, Full Priority and Full Compensation in Corparate Reorganization-A Reappraisal, 25 U. CHI. L. REv. 417, 444 (1958):

To those who are primarily concerned with the plight of junior interests in financially distressed companies... an "expansible valuation" or "maximum permissible capitalization" approach will seem best.

"Jacking up value is an obvious device for circumventing the absolute priority rule." Gardner, supra note 26 , at 456-57.

31. This is true especially in railroad reorganization cases under Section 77, but apparently is true in Chapter $X$ cases as well. Note, Valuation by the SEC in Reorganization, 55 HARv. L. REv. 125, 132-34 (1941); Blum, Law and Language, supra note 14; Brudney, supra note 5, at 679; Friendly \& Tondel, supra note 20. See Reconstruction Fin. Corp. v. Denver \& R.G.W. R.R., 328 U.S. 495 (1946), and its aftermath in Guaranty Trust Co. v. Chase Nat'l Bank, 302 N.Y. 658, 98 N.E.2d 474, cert. denied, 342 U.S. 819 (1951). For a good analysis of the actual monetary outcomes from the process of satisfaction in reorganization value equivalents, see Billyou, supra note 15, at 570-71 \& n.61; cf. Florida East Coast Ry., 282 I.C.C. 81, 115, 158-59 (1951) (the ICC compares the probable market values of the securities with their reorganization values). 
liquidation-based rights. ${ }^{32}$ Nevertheless, since the proponents of this approach assert that market value is expected eventually to equal the reorganization value, they are able to conclude that the absolute priority rule enjoys strict adherence. ${ }^{33}$

\section{The Role of the Bonus Rule in Chapter $\mathrm{X}$}

Were the senior security holders always to have their claims satisfied by the receipt of securities qualitatively identical to those they possessed in the enterprise prior to the reorganization (i.e., bonds for bonds, common stock for common stock), the process would be at an end. The old senior security holders would be deemed paid in full if the court-assigned face value of the new but qualitatively identical securities were quantitatively identical to their liquidation-based claims. $^{3 *}$

The usual process of reorganization, however, involves a qualitative shifting of securities, for example, exchanging bonds of the old corporation for common or preferred stock of the reorganized corporation..$^{35}$ The reason for such a shift is typically to reduce the en-

32. Once a hicrarchy of interests is established, each class must receive $100 \%$ satisfaction before the next lower class may participate at all.... However-and this is a vitally important corollary-100\% satisfaction is deemed to be given by $100 \%$ satisfaction in paper. Priorities are considered satisfied if the full amount of the claim is recognized in securities of the appropriate dollar amount. No attempt has been made to insist that the securities issuable to a senior class must have a prospective market value of 100 cents on the dollar before a junior class may participate.

Friendly \& Tondel, supra note 20 , at 423 . At least one early reading of Consolidated Rock Prods. Co. v. DuBois, 312 U.S. 510 (1941), reached the conclusion that the case required payment in market value equivalents. See Dean, $A$ Review of the Law of Corporate $R e-$ organization, 26 CoRNELL L.Q. 537, 559 n.63 (194I). It quickly became clear, however, that market equivalence was not required. See sources cited in note 31 supra; Blum, Law and Language, supra note 14 , at 571 .

It has been argued that "full satisfaction" has been achieved if the surrendering senior security holders "receive, for their total claim, a par amount of new securities having a reasonable prospect of selling for the amount of the claims for which they were exchanged," even though not immediately equal to that amount in cash. Missouri Pacific R.R., 290 I.C.C. 477,555 (1954), plan approved sub nom. In re Missouri Pac. R.R., 129 F. Supp. 392 (E.D. Mo.), aff'd sub. nom. Missouri Pac. R.R. 51/2\% Sec. Serial Bondholders Comm. v. Thompson, 225 F.2d 761 (8th Cir. 1955), cert. denied, 350 U.S. 959 (1956). See generally Brudney, supra note 5, at 672; cf. Frank, supra note 26, at 340 . Even this process of "waiting" for full compensation may not be fair to the senior security-holders. See, e.g., V. BRUdNey \& M. ChIRelstein, supra note 20, at 33; cf. New Haven Inclusion Cases, 399 U.S. 392, 485.87 (1970).

33. Jerome Frank, while Chairman of the SEC, wrote:

We believe that senior security holders are entitled to receive more than mere paper securities of a face amount equal to their claims; and that the securities they receive should be such as to give them really compensatory treatment for their claims. In other words, the new securities should be intrinsically sound, so that there is a reasonable prospect that they will have values equal to their face amount....

Frank, supra note 26 , at 340 .

34. Friendly \& Tondel, supra note 20, at 424; Billyou, supra note 15, at 570-72 n.61.

35. See, e.g., Frye, The "Fair and Equitable" Doctrine: Are Liquidation Rights a Realistic Standard During Corporate Reorganizations?, 20 CATH. U.L. REv. 394, 400-01 (1971). 
terprise's fixed interest charges, themselves often a precipitating cause of the bankruptcy reorganization, or to simplify the security structure. ${ }^{36}$ The result is that senior security holders are often paid in securities of a lower qualitative ranking than those they previously possessed. ${ }^{37}$

In Consolidated Rock Products Co. v. DuBois, ${ }^{38}$ the Supreme Court confronted this shifting of relative priorities. ${ }^{39}$ Justice Douglas, writing for a unanimous court, perceived that such a qualitative shifting might be used to evade the absolute priority rule. Consequently, he announced in his holding what has become known as the bonus rule:

Thus it is plain that while creditors may be given inferior grades of securities, their "superior rights" must be recognized. Clearly, those prior rights are not recognized, in cases where stockholders are participating in the plan, if creditors are given only a face amount of inferior securities equal to the face amount of their claims. They must receive, in addition, compensation for the senior rights which they are to surrender. If they receive less than that full compensatory treatment, some of their property rights will be appropriated for the benefit of stockholders without compensation. That is not permissible. ${ }^{40}$

The rule has become a principal element of Chapter $\mathrm{X}$ proceedings. ${ }^{41}$

36. Note, Distribution of Securities in Corporate Reorganization, 51 YALE L.J. 85, 96-97 (1941).

37. Consolidated Rock Prods. Co. v. DuBois, 312 U.S. 510, 528 (1941); In re Barlum Realty Co., 62 F. Supp. 81, 87 (E.D. Mich. 1945), aff'd, 154 F.2d 562 (4th Cir.), modified, 157 F.2d 408 (4th Cir. 1946); Blum, Law and Language, supra note 14, at 583; Calkins, Feasibility in Plans of Corporate Reorganization Under Chapter $X, 61$ HARv. L. REv. 763, 763 (1948); Comment, supra note 15, at 660; Note, supra note 20, at 903 n.22.

38. 312 U.S. 510 (1941).

39. Justice Douglas acknowledged that the process of reorganization did not prohibit per se the satisfaction of claims with qualitatively different securities:

The absolute priority rule does not mean that bondholders cannot be given inferior grades of securities, or even securities of the same grade as are received by junior interests. Requirements of feasibility of reorganization plans frequently necessitate it in the interests of simpler and more conservative capital structures. And standards of fairness permit it.

Id. at 528 .

40. Id. at 528-29. The SEC apparently had arrived at a similar formulation of the bonus rule shortly before Justice Douglas's pronouncement. See Deep Rock Oil Corp., 7 S.E.C. $174(1940)$. The SEC there thought that a bonus called for in the plan, approximately 10 percent over the amount of the claim, was appropriate "even accepting the appraised value" on which the reorganization process had been premised. Id. at 194. A lower court decision in that case, handed down two months prior to Consolidated Rock Prods. Co. v. DuBois, 312 U.S. 510 (1941), also applied a bonus rule, noting that " $t]$ he noteholders are entitled to compensation for the loss of priority." Standard Gas \& Elec. Co. v. Deep Rock Oil Corp., 117 F.2d 615, 616-17 (10th Cir.), cert. denied, 313 U.S. 564 (1941); cf. 'T. Finletter, Principles of Corporate Reorganization 410 (1937) (secing the necessity for a "quid pro quo"); T. FinLErrer, supra note 21, at 442.

41. See, e.g., Group of Institutional Investors v. Chicago, Mil., St. P. \&. Pac. R.R., 318 U.S. 523, 557-66 (1943); Central States Elec. Corp. v. Austrian, 183 F.2d 879, 888-89 (4th Cir. 1950), cert. denied, 340 U.S. 917 (1951); cf. Yale Express Systems, Inc., SEC Corp. Reorg. Release No. 309, at 24 (Jan. 14, 1972). Blum writes that the language of Justice 
Justice Douglas' bonus rule, however, contains an apparent anomaly. If only reorganization values are to be used in Chapter $\mathrm{X}$ proceedings (and the policy clearly establishes this), then the face value of the new securities which will be given out to represent that reorganization value must, for the purposes of the reorganization process, be assumed correct, since the reorganization value of the enterprise assigned by the court is assumed correct, and the sum of the face values must aggregate to that reorganization value.42 Thus the face value of a new security certificate must equal, insofar as the court administering Chapter X is concerned, "actual" value. Hence, if old senior security holders are compensated with new junior securities (or, indeed, vice versa), quantitatively neither a bonus nor a penalty would be required to balance the change in qualitative status. To apply a bonus or a penalty, that is to suggest, would be analogous to falling into the error of assuming that a ton of feathers indeed weighed less than a ton of lead.

The bonus rule, as a result, has been criticized ${ }^{43}$ for being inherently in conflict with the courts' refusal to use the market in valuing the enterprise. If indeed the Chapter $\mathrm{X}$ process recognized only face values, the bonus rule would be unjustifiable. Once the theoretical structure of the current system of reorganization is properly understood, however, the bonus rule is compatible not only with the practice of bankruptcy reorganization, but also with the theory behind Chapter $\mathrm{X}$.

\section{A. Justifying the Bonus Rule in Practice}

As a practical matter, it is apparent that there usually will be a divergence between the face and the market value even of a qualitatively identical new security in the reorganized enterprise. The old seniors

Douglas "has become the touchstone of the full compensation doctrinc." Blum, Corporate Reorganization Doctrine, supra note 10, at 107 .

The logic of Justice Douglas's bonus rule scemed compelling, with the result that commentators quickly accepted the bonus rule as a logical extension of the absolutc priority rule. Frank, supra note 26, at 346; Gardner, supra note 26, at 460; Comment, supra note 15 , at 660 .

42. See note 27 supra.

43. This contradiction was recently explained by Professor Blum:

If that valuation [placed on the entire enterprise] is approved, then, logically, the

value attributed to the new common stock-computed by deducting the principal or

par amount of all higher ranking securities from the total enterprise value-must also

be accepted as correct. Doubt about the value of the common necessarily translates into doubt about the valuation of the firm itself. The very acknowledgement of need

for a quantitative "bonus" to creditors receiving the common is an admission that the firm has been overvalued.

Blum, Corporate Reorganization Doctrine, supra note 10, at 110 (emphasis added) (concludes that "[a]n oblique modification of that valuation by way of a 'bonus'... should not be condoned"). 
suffer an additional loss, however, if their claims are satisfied with qualitatively different securities, at least where they are lumped together with those who formerly held an inferior security. ${ }^{44}$ Because of the different risk characteristics inherent in the various securities, the impact of the gap between market and reorganization value, equivalent to a one-shot decline in enterprise value, ${ }^{45}$ will not fall proportionately over the spectrum of the capital structure. Rather, it will fall more heavily on the junior securities ${ }^{4 \mathfrak{b}}$ because the more junior end of a capital structure encompasses securities that have assumed a proportionately greater risk of such a decline. ${ }^{47}$ Thus, when the old senior security holders are paid with new junior securities rather than with new senior securities an additional portion of the enterprise value. shifts to those holders of new junior securities who held only junior securities in the old firm. ${ }^{48}$ Viewed in this manner, it is apparent that

44. It is necessary to stress that the bonus rule should be applicable only when there may be said to be a comparative shift in quality between old senior and junior security holders. This may be seen most persuasively, perhaps, in a situation where the old senior security holders were holders of 5 percent income debentures whereas the only junior security holders remaining after valuation were participating preferred. There would seem to be no reason for the application of the bonus rule if the debenture holders were satisfied with preferred, and the old preferred satisfied with common. The old seniors still will have a first entitlement on the same proportion of the enterprise's income stream as if they had been given a comparable new security. The bonus rule would be called into play, in this example, only if both classes were to be compensated out of the same security class. As long as the old seniors maintain priority (and their interest rate does not change), the bonus rule should not be necessary. The phrase "qualitatively inferior security" is used to represent this constellation of considerations.

45. See, e.g., Blum, Full Priority, supra note 15, at 437. That is, a one-shot decline occurs when the differential between reorganization and market values is finally recognized.

46. This may be seen by pursuing the analogy of a one-shot decline. A sudden loss will hit the value of the common harder, because the troubled corporation will decrease or eliminate dividends long before it will tamper with the bondholders' fixed interest rights.

47. See generally H. Guthmann \& H. Dougall, supra note 1 , at 67.123 .' It is commonly recognized in security analysis that the price placed on a security by the individuals in the market is a function not only of the security's expected return, but also of the degree of risk associated with that expected return. See V. BRUDNEY \& M. ChIREesteIn, supra note 20 , at 56,1109 .

48. This may be demonstrated by example. Corporation $R$ is in reorganization under Chapter $X$, and the reorganization court has declared a reorganization value of $\$ 150,000$. Corporation $R$ has two classes of securities: bonds, with a liquidation claim of $\$ 100,000$, and common, with a claim to the residue. The market, however, is not so sanguine about the future, and foresees the following probability distribution of expected enterprise values:

$\begin{array}{cc}\text { MARKET VIEW OF CORPORATION R } \\ \text { Expected } & \\ \text { Enterprise Value } & \text { Probability } \\ \$ 150,000 & .10 \\ 120,000 & .20 \\ 100,000 & .40 \\ 80,000 & .20 \\ 50,000 & .10\end{array}$

If the court retains the security structure of the reorganized enterprise-thereby giving the bondholders qualitatively equivalent securities-the absolute priority rule would be 
the bonus rule is a necessary tool to ensure that the degree of sacrifice imposed upon senior security holders due to a discrepancy between the reorganization and the market value of the enterprise does not depend on the fortuity of the type of security they are to receive in the reorganized enterprise.

\section{B. Justifying the Bonus Rule in Theory}

The foregoing demonstrates that the bonus rule's practical justification depends on the recognition of a discrepancy between the reorganization and the market values of the enterprise. But traditional corporate reorganization theory rejects the relevance of market valuation. In order to justify the presence of the bonus rule in the theory of Chapter $\mathrm{X}$, it is necessary to justify the recognition, at some point, of a discrepancy between market and reorganization value. Further, the justification needs to be developed without overthrowing the courts' consistent refusal to recognize such a discrepancy during the

deemed satisfied. The market's calculation of the bondholders' expected return and associated risk appears as follows:

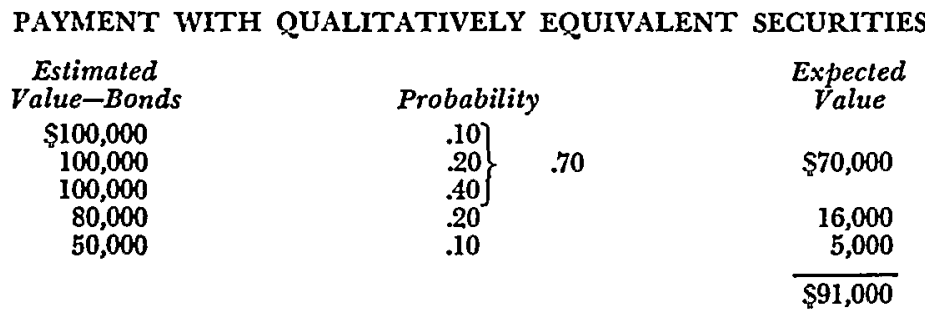

The bondholders, given qualitatively equivalent bonds, would therefore find that they had an expected value of return of $\$ 91,000$. See V. BrudNEY \& M. CHIRELSTEIN, supra note 20 , at 49.66 .

If the court decides instead to use an all common security structure, then to give the bondholders only the face amount of their claim would leave them worse off. Since their claim is $\$ 100,000$, they would receive, if there were no bonus rule, $\$ 100,000$ of face-value common, or two-thirds of the total amount of common:

PAYMENT WITH QUALITATIVELY INFERIOR SECURITIES

$\begin{array}{ccc}\text { Estimated } & & \text { Expected } \\ \text { Value-Bonds } & \text { Probability } & \text { Value } \\ \$ 100,000 & .10 & \$ 10,000 \\ 80,000 & .20 & 16,000 \\ 66,667 & .40 & 26,667 \\ 53,333 & .20 & 10,667 \\ 33,333 & .10 & 3,333 \\ & & \$ \$ 66,667\end{array}$

The bondholders, here compensated with $\$ 100,000$ of reorganization value common, would find they now had an expected value of return of $\$ 66,667$ and with a greater downside potential than before. Clearly, therefore, a discrepancy between reorganization and market values creates a discrepancy in the quantity of actual payment made that will depend on the quality of the securities received. See note 47 supra. 
valuation process itself, since that refusal is essential to the claim that the absolute priority rule enjoys strict adherence. ${ }^{49}$

This theoretical justification may be provided by viewing the Chapter $\mathrm{X}$ procedure as a process encompassing two discrete stages. Under this view, at the first stage the courts are concerned with the surrogate liquidation process: They are interested in valuing the rights of the various classes of security holders that would have existed upon a liquidation. At this stage the courts are not yet concerned with the viability of the enterprise as a going-concern. What is determined at this stage are the claims and the total value of the enterprise from which those claims are to be satisfied. ${ }^{50}$ The first stage, therefore, only involves a process of determining how large the enterprise value is, in order to determine which groups of security holders will be permitted to retain an interest in that corporation. It is not yet necessary to determine the viability of the corporation's security structure.

More precisely, this first stage is dominated by the Chapter X requirement that reorganizations be "fair and equitable" 51 - the requirement of absolute priority. At this stage, as the courts have indicated, the market value is irrelevant..52 Questions of whether operations after reorganization are feasible are also irrelevant at this first stage. The court is concerned with meeting a liquidation-based absolute priority rule in measuring and paying claims, and not with the feasibility of a going-concern.

It is appropriate, therefore, to consider the capital structure of the reorganized company at this stage as unchanged from the pre-reorganization capital structure. ${ }^{53}$ Once it has been determined by this process which groups of security holders are entitled to participate in the reorganized company, then those security holders may be considered to be given, in satisfaction of their claims, the new, but qualitatively identical, securities. Payment in qualitatively equivalent securities is not required in Chapter $\mathrm{X}$ reorganization, ${ }^{54}$ but it always remains an alternative. If qualitatively identical securities are given out upon reorganization, then under the current system the absolute prior-

49. See pp, $938-39$ supra.

50. See pp.934-36 supra; Blum \& Kaplan, supra note 14, at 655 .

51. Bankruptcy Act § 221(2), I1 U.S.C. § 621(2) (1970).

52. See pp. 936-39 supra.

53. This capital structure equivalence would continue, of course, only as long as the reorganization value of the enterprise is great enough to permit further classes of junior security-holders to participate.

54. Nor could qualitative equivalence be required, in a general system of reorganization which had as a goal the financially stable continuation of economically viable enterprises. Reorganization typically scales down fixed interest charges. See 2 A. DEWING, supra note 2 , at 1246-97, 1436-39. 
ity rule is deemed fulfilled as long as the face amount of the new, qualitatively identical, securities equals the total of the security holder's claim. In such a case, the bonus rule does not apply; the security holders are considered satisfied in full, no matter what is the size of the arguable gap between face value and market value of the securities they now own. Payment in qualitative equivalents, therefore, may be taken as the standard of satisfaction against which a different form of satisfactionsuch as "inferior" securities-is to be measured. That is, for any other form of payment equally to satisfy the absolute priority rule, each class of security holders must be in no worse a position under such alternative payment than it would have been under the qualitative equivalence exchange.

Once the qualitatively equivalent securities have been "given" in satisfaction of the claims, the first stage may be considered complete and a second stage begins. It is a recapitalization, focusing on the enterprise as a going-concern and dominated by the statutory requirement that the plan be "feasible." 55 Creating a feasible capital structure usually requires a qualitaiive shifting of securities. But the fair and equitable standard does not evaporate in this stage; it still forbids a shift in value from the old senior to the old junior security holders.

Since this second stage of the reorganization process may be viewed as a discrete step, it is not contradictory to suggest that market or going-concern values may be the relevant criteria here, although they were not relevant in Stage One. The bonus rule, as a consequence, naturally enters this second stage, because the old senior security holders should be compensated quantitatively for the loss of priority they sustain when they are asked to accept qualitatively junior securities solely in order to make the reorganization plan "feasible."

Whether viewing the process of reorganization in terms of a twostage process is reasonable under the present practices of Chapter $\mathrm{X}$ depends on whether it is logical to view "feasible" as a standard sufficiently separate from "fair and equitable" to justify treating the two standards as keystones of successive stages. Bonbright and Bergerman, writing in 1928, before the Bankruptcy Act codified the language, suggested that the two standards were sufficiently separate:

Fairness is the aspect that is concerned with the equitable division of the new securities among the various parties at interest. It is concerned only incidentally with the effectiveness of the

55. Bankruptcy Act $§ 221(2)$, 11 U.S.C. $\$ 621(2)$ (1970). See SEC, AdvisoRY REPORT IN RE YubA Consol. Indus., Inc. 28-29 (1965), quoted in In re Yuba Consol. Indus. Inc., $242 \mathrm{~F}$. Supp. 561, 570 (N.D. Cal. 1965). 
reorganization plan in restoring the property to financial and economic well-being. This latter consideration, to be sure, is much the more socially important of the two; so important, indeed, that it quite properly conditions the whole thing as to a fair distribution of the new securities among the old security holders. But, for purposes of analysis the two problems can, to some extent, be treated separately. ${ }^{56}$

The term "fair and equitable" in Chapter X spawned the absolute priority rule, ${ }^{57}$ which was developed to deal with the question of the precedence to be accorded senior creditors over equity and junior creditor interests upon the occurence of the financial event that confronted the firm with the choice of liquidation, equity receivership, or reorganization. ${ }^{58}$ Feasibility, on the other hand, entails significantly different perspectives. ${ }^{59} \mathrm{It}$ is not a standard based upon liquidation. Instead, it is forward-looking, concentrating on the going-concern success of the enterprise emerging from reorganization, not on the liquidation rights of the security holders. ${ }^{60}$

56. Bonbright \& Bergerman, supra note 18, at 128. See Brudney, supra note 5, at 677.

57. See note 18 supra; 18 SEC ÂNN. REP. 156 (1952).

58. Case v. Los Angeles Lumber Prods. Co., 308 U.S. 106, 115-17 (1939).

59. 6A Collier on BANKruptcy If 11.04, at 586-87; I 11.07, at 637-38 (14th ed. 1972).

60. 6 SEC ANN. ReP. 65 (1940); 16 SEC ANN. REP. 128 (1950); S. REP. No. 1916, 75th Cong., 3d Sess. 36 (1938); SEC, supra note 24, at 159. Professor Blum was thinking in these conceptual terms when he wrote:

This formula [i.e., of a "fair plan"] assumes that the seniors receive new paper thought to be equivalent in quality, as well as in normal quantity, to their old holdings. In most situations that arrangement would undermine the rehabilitation operation by preserving fixed charges that are heavy in relation to estimated earnings. The statutory requirement that a plan be feasible as well as fair usually necessitates a more or less drastic scaling down of such obligations and this ordinarily can be accomplished only by reducing the quality of paper allocated to the seniors.

Blum, Law and Language, supra note 14, at 58. See Calkins, supra note 37, at 763; Note, supra note 25, at 466; Note, supra note 36 , at 91-92. Feasibility, therefore, is conceptually distinct from the Chapter $\mathrm{X}$ fair and equitable standard: its concern is with the future life of the company, not with a substitute for an otherwise ensuing death.

The courts have consistently recognized that the standard embodied in "feasible" is a distinct standard from that embodied in "fair and equitable" and calls, consequently, for a different focus, and different concerns. See General Stores v. Shlensky, 350 U.S. 462 , 467-68 (1956); In re Waern Bldg. Corp., 145 F.2d 584, 589 (7th Cir. 1944), cert. denied, 324 U.S. 871 (1945); New Eng. Coal \& Coke Co. v. Rutland R. Co., 143 F.2d 179, 186 (2d Cir. 1944); Wayne United Gas Co. v. Owens-Illinois Glass Co., 91 F.2d 827, 830 (4th Cir. 1937); In re Spectrum Arena, Inc., 340 F. Supp. 767, 780 (E.D. Pa. 1971); In re Barlum Realty Co., 62 F. Supp. 81, 87 (E.D. Mich. 1945); In re Philadelphia \& W. Ry., 51 F. Supp. 129, 130 (E.D. Pa. 1943). The SEC has consistently applied the "fair and equitable" standard distinctly from the "feasible" standard, much as the courts have. 5 SEC ANN. REP. 14-16 (1939). See, e.g., International Ry. Co., SEC Corp. Reorg. Release No. 76, at 18-33 (June 30, 1949); Childs Co., SEC Corp. Reorg. Release No. 67, at 32-48 (Sept. 30, 1946); Cenwest Co., SEC Corp. Reorg. Release No. 59, at 7-9 (Feb. 1, 1944); Hudson \& Manhattan Ry. Co., SEC Corp. Reorg. Release No. 110, at 34-42 (Dec. 2, 1958); Four Seasons Nursing Centers of America, Inc., SEC Corp. Reorg. Release No. 310, at 40-57 (Mar. 16, 1972). 
III. Implementing the Bonus Rule: The Investment Value Doctrine

In implementing the bonus rule, courts have been unable to formulate a uniform and precise method of measuring the bonus; in Chapter $\mathrm{X}$ opinions, bonuses just appear, like pansies in the spring. ${ }^{01}$ However, there is precedent under a similar statute, the Public Utilities Holding Company Act of $1935,{ }^{62}$ that can improve the courts' bonus calculations. Section 11 of that Act made statutory reorganization mandatory on non-defaulting-indeed, often very successful-enterprises in order to simplify the inordinately complex structures that characterized the public utility industry. ${ }^{63}$ In Section 11 , the SEC and the courts rejected the use of contractual liquidation rights to measure claims, on the ground that Congress's mandate to simplify was a mandate to restructure the capital system of the enterprise, but without shifting values within a going-concern. ${ }^{04}$ "Feasibility" is the analogous statutory mandate of the second stage of Chapter X, calling for reform of the capital structure of the enterprise so as to ensure its success as a going-concern. Consequently, the analysis undertaken for Section 11 is appropriate here: It should be assumed that Congress did not intend to shift values at this point in Chapter $\mathrm{X}$ proceedings-to do so would be to undermine the prior operation of the absolute priority rule-merely because of a recapitalization of the security structure pursuant to the statutory mandate of feasibility.

The bonus rule was designed to ensure that such a shift does not occur. ${ }^{65}$ It is appropriate, therefore, to give content to the bonus rule

61. Cf. Central States Elec. Corp. v. Austrian, 183 F.2d 879, 888 (4th Cir. 1950); Standard Gas \& Elec. Co. v. Deep Rock Oil Corp., 117 F.2d 615, 616-17 (10th Cir.), cert. denied, 313 U.S. 564 (1941); In re Midland United Co., 58 F. Supp. 667, 684-85 (D. Del.), appeal dismissed, 141 F.2d 692 (3d Cir. 1944), later proceeding, 64 F. Supp. 399 (D. Del. 19.6), aff'd, 159 F.2d 340 (3d Cir. 1947); In re Alabama, Tenn. \& N. R.R., 47 F. Supp. 694, 708-09 (S.D. Ala. 1942).

62. is U.S.C. $\$ 79 \mathrm{k}(1970)$.

63. 25 SEC ANN. REP. XXV-XXVI (1959) (foreword).

64. Otis \& Co. v. SEC, 323 U.S. 624,638 (1945):

Congress did not intend that its exercise of power to simplify should mature rights, created without regard to the possibility of simplification of system structure, which otherwise would only arise by voluntary action of stockholders or, involuntarily, through action of creditors. We must assume that Congress intended to exercise its power with the least possible harm to citizens.

See, e.g., 15 U.S.C. \$ 79k(a) (1970); SEC v. Central-Illinois SEC Corp., 338 U.S. 96, 131, 140 (1949); Lahti v. New Eng. Power Ass'n, 160 F.2d 845 (1st Cir. 1947) (Magruder, J.); In re The United Corp., 128 F. Supp. 725, 727, 731, 738 (D. Del. 1955); S. REr. No. 621, 74th Cong., lst Sess. 21, 56, 59 (1935); cf. id. at 2 (Report by President F. Roosevelt to Congress).

65. The second stage is the stage concerned with the functioning of the bonus rule, and the bonus rule means, in practice, that the going-concern value of what is received must equal the going-concern value of what would have been received had the claims been satisfied with qualitatively equivalent securities. The "bonus" arises because such a going-concern equivalence is achieved only when the face value of the qualitatively inferior payment is greater than the amount of the liquidation-based claim to be surrendered. 
by adopting its counterpart under Section 11, the investment value doctrine. That doctrine demands that each class of security holders receive securities in the reorganized enterprise equivalent to the value of their investments in the old enterprise (not the value of their liquidation rights). Investment value, it should be stressed, does not enter into the first stage of Chapter X; it plays no role in deciding who will participate in the reorganized enterprise, and so it does not undermine the absolute priority rule. ${ }^{86}$ Instead the doctrine enters only at the second stage. Using the first stage as a base, it merely aids in the decision as to how the various classes are to participate.

A series of related examples, illustrated in Table I, demonstrates the equivalence between the bonus rule and the investment value doctrine and shows how Section 11 principles will be used only in the second stage of the Chapter $\mathrm{X}$ process.

Assume first a company involved in a Section 11 proceeding. Prior to this proceeding, the company has bonds with a market or going-

66. The scheme suggested here therefore is not subject to the criticisms summarized in note 15 supra. Professor Brudney's objection, that the going-concern valuc would measure the claim in terms of the going-concern value of an enterprise that has failed, is likewise not applicable here. See Brudney, supra note 5, at 671. For, instead of measuring the claim to be satisfied per se, the investment value doctrine, utilized at this second stage, compares the going-concern values of different securities within the corporation. If the going-concern value of a senior security is depressed, nonetheless it is being used as the standard against which the going-concern value of a junior security, which will, by hypothesis, be even more depressed, is being measured.

The debate in the 1950's between the proponents and opponents of applying the investment value doctrine in Chapter $\mathrm{X}$, see note 15 supra, apparently focused only on the claims side of the claims-payment equation, perhaps as a result of the fact that the investment value doctrine in Section 11 was primarily discussed in terms of the measurement of claims; cf. note 15 supra. On that ground, the opponents of the doctrine were undoubtedly correct; if the process of measuring payment remained the same, to change the method of valuing claims would upset the equation. The policy of Section 11 that investment values should not be shifted demands, of course, that going-concern values, and not face values, be used for measuring payment as well as for measuring claims. See Brudney, supra note 5, at 662; cf. Otis \& Co. v. SEC, 323 U.S. 624, 639-40 (1945). Only in that manner could it be asserted that going-concern values have not shifted; that assertion could not be made, for example, if going-concern values were used to measure claims while face values were used to measure payment. And, in cases arising under Section 11, payment was indeed measured in the identical terms in which claims were measured. Sce, e.g., Eastern Gas \& Fuel Associates, 30 S.E.C. 834, 909-16, 919 (1950).

It follows that the investment value doctrine, if used on both the claims and payment side of the equation, would lead to a result similar to that reached under the current Chapter $\mathrm{X}$ system. In Table I, infra, for example, compare Charts 2; 3 with Charts 6, 9. That this is so may be seen by remembering that the current Chapter $X$ process, by the inflating of payment values, accompanied by the use of face values to measure payment, means that senior security-holders are not, in reality, paid 100 cents on the dollar, see pp. 938-39 \& note 32 supra. Thus Chapter $X$ as it presently exists already undermines the expectations of the senior security-holders: it already hurts the seniors. The investment value analysis, using a deflated standard-that of going-concern values-on both sides of the equation would not cause significant further harm to the seniors.

For the purposes of this Note, however, it is not crucial to discover whether the proponents and opponents of the investment value analysis focused, perhaps incorrectly, only on the claims side of the claims-payment equation. It has by now been firmly established that corporate reorganization law demands the use $a b$ initio of liquidation rights to measure claims. See pp. 934-35 supra. For that reason, the investment value doctrine is inappropriate, at least in the first stage where claims are measured. 


\section{TABLE I}

Section 11 Proceeding

1

\begin{tabular}{lcc} 
& \multicolumn{2}{c}{ Before } \\
Bonds & 100,000 & Market \\
Preferred & 95,000 \\
Common & residu...... & $\ldots \ldots \ldots \ldots$ \\
\cline { 2 - 2 } & & 15,000 \\
\cline { 2 - 2 } & & 110,000
\end{tabular}

\section{2}

Face ${ }^{\text {After }}$ Market

$52,000 \quad 50,000$

$55,000 \quad 50,000$

residual

$\frac{10,000}{110,000}$

3

New Securities

Distribution To Old

Bondholders

Face Market

$52,000 \quad 50,000$

$49,500 \quad 45,000$

$\stackrel{1 \cdots \cdots}{101,500} \quad \frac{\cdots \cdots}{95,000}$

\begin{tabular}{|c|c|c|c|c|c|c|}
\hline \multicolumn{7}{|c|}{ Chapter $\mathrm{X}$ Proceedings } \\
\hline & \multicolumn{2}{|c|}{4} & \multicolumn{2}{|c|}{$\mathbf{5}$} & \multicolumn{2}{|c|}{6} \\
\hline & \multicolumn{2}{|c|}{$\begin{array}{l}\text { Liquidation Claims } \\
\text { Entering Chapter X }\end{array}$} & \multicolumn{2}{|c|}{$\begin{array}{c}\text { After } \\
\text { Stage One }\end{array}$} & \multicolumn{2}{|c|}{$\begin{array}{c}\text { After } \\
\text { Stage Two }\end{array}$} \\
\hline & $\begin{array}{l}\text { Liquidation } \\
\text { Claims }\end{array}$ & Market & Face & Market & Face & Market \\
\hline \multirow{4}{*}{$\begin{array}{l}\text { Bonds } \\
\text { Preferred } \\
\text { Common }\end{array}$} & 100,000 & 95,000 & - 100,000 & 95,000 & 52,000 & 50,000 \\
\hline & (.................. & $\ldots . . . . . . .$. & & & 55,000 & 50,000 \\
\hline & residual & 15,000 & 20,000 & 15,000 & 13,000 & 10,000 \\
\hline & & 110,000 & 120,000 & $\overrightarrow{110,000}$ & 120,000 & $\overline{110,000}$ \\
\hline
\end{tabular}

New Securities Distribution to Old Bondholders

\begin{tabular}{|c|c|c|c|c|c|c|}
\hline & & One & St & $\begin{array}{l}\text { Two } \\
\text { us Rule) }\end{array}$ & $\underset{\text { Sitc }}{\text { Soi }}$ & $\begin{array}{l}\text { [wo } \\
\text { Rule) }\end{array}$ \\
\hline & Face & Market & Face & Market & Face & Market \\
\hline $\begin{array}{l}\text { Bonds } \\
\text { Preferred }\end{array}$ & $\begin{array}{r}100,000 \\
\ldots \ldots \ldots . . . . .\end{array}$ & $\begin{array}{r}95,000 \\
\ldots \ldots \ldots \ldots . . . . .\end{array}$ & $\begin{array}{l}52,000 \\
48,000\end{array}$ & $\begin{array}{l}50,000 \\
43,636\end{array}$ & $\begin{array}{l}52,000 \\
49,500\end{array}$ & $\begin{array}{l}50,000 \\
45,000\end{array}$ \\
\hline & & & 100,000 & 93,636 & 101,500 & 95,000 \\
\hline
\end{tabular}

concern value of $\$ 95,000$, and common stock with a market value of $\$ 15,000 .{ }^{67}$ The face value of the bonds is $\$ 100,000$, although this figure is not itself relevant to the Section 11 proceeding. The market value of the company, computed by adding together the market values of the component securities, is $\$ 110,000$. A court holds, under Section 11, that the corporation must reform its capital structure so that the company has $\$ 52,000$ face value of bonds and $\$ 55,000$ face value of preferred stock. Let us say that the market values after restructuring are $\$ 50,000$, for each of these two classes, and $\$ 10,000$ for the common. ${ }^{68}$

67. See Table I, Chart I.

68. The market value of the enterprise, therefore, again is $\$ 110,000$. See Table I, Chart 2. 
The investment value doctrine requires that the old bondholders be given new securities so that the market value of their investment in the enterprise does not change. Since that value was $\$ 95,000$ before, it must be $\$ 95,000$ after as well. Thus, the old bondholders should receive all of the new bonds plus 90 percent of the new preferred stock, since the aggregate market value of the securities they would then hold is $\$ 95,000$. We may note that the old bondholders, who had bonds with a face value of $\$ 100,000$, have been paid with securities whose face value equals, not $\$ 100,000$, but $\$ 101,500 .{ }^{69}$

The example now shifts to a Chapter X situation. In Chapter X claims are measured by liquidation rights of the old securities and payments by face value of the new securities as assigned by the court out of the total reorganization value. An enterprise identical to the initial enterprise in the Section 11 example enters Chapter X: The market value of the bonds totals $\$ 95,000$, and of common, $\$ 15,000 .^{70}$ Let us say that the court determines the reorganization value to be $\$ 120,000$, out of which the bondholders have a liquidation-based claim of $\$ 100,000 .{ }^{71}$ For Stage One we posit no qualitative shift, hence no change in the security structure. ${ }^{72}$ The reorganized company will be as illustrated in Table I, Chart 5 , and the fair and equitable standard will be satisfied if the bondholders are given new but qualitatively identical bonds with a face value of $\$ 100,000 .{ }^{73}$ Since there has been no qualitative shift, the bonus rule, by its own definition, does not apply. In this case we may note that the liquidation-based claim of the old bondholders of $\$ 100,000$ has been met by payment with securities which, while having a face value of $\$ 100,000$, have a market value of $\$ 95,000.74$

Now the enterprise enters Stage Two. The court determines to reduce the interest payments the new corporation must make by shifting the security structure of the enterprise in reorganization. It decides

69. See Table I, Chart 3.

70. The bondholders therefore have bonds with a liquidation claim, and a face value, of $\$ 100,000$. See Table I, Chart 4.

71. Since the reorganization value of the enterprise is $\$ 120,000$, and the bondholder's claim is $\$ 100,000$, the residual value to the common is $\$ 20,000$. See Table I, Chart 5 .

72. Stage One could itself represent a complete Chapter $X$ reorganization. Since the reorganization value is $\$ 120,000$, common stockholders will still be allowed to participate in the reorganized enterprise; Stage One thus seems a rather undramatic construct in this simplified example. In more complicated examples with a lower reorganization value, the most important function of the first stage would be revealed: The enterprise value would be insufficient to meet the liquidation-based claims of all classes. One or more classes would be excluded and only the survivors would be considered in the Stage Two calculations, which would nonetheless yield a result like that obtained under the investment value doctrine.

73. See Table I, Chart 7 .

74. This follows from the fact that $\$ 100,000$ face value of bonds has a going-concern value of $\$ 95,000$. 
that a structure of $\$ 52,000$ face value of bonds, and $\$ 55,000$ face value of preferred is feasible. ${ }^{75}$ The old bondholders, of course, still have a liquidation claim of $\$ 100,000$. Apart from the bonus rule, it is clear that the Chapter $X$ court considers the $\$ 100,000$ claim satisfied with $\$ 100,000$ face value of new securities-that is to say, $\$ 52,000$ face value in new bonds and $\$ 48,000$ face value in new preferred stock. The market value of this $\$ 100,000$ face value payment is $\$ 93,636 .^{76}$

Chapter X theory, however, requires that a bonus is necessary as a result of the qualitative shift and, indeed, when the two Chapter X stages are compared, it is clear that a bonus is necessary in the second case. ${ }^{77}$ But the bonus need not be designed to give the old bondholders securities with a market value of $\$ 100,000$, their liquidation claim. Rather, the first stage, where there was no qualitative shift, provides the standard: the cash equivalent must be $\$ 95,000$. To be as well off, the old bondholders in the second case need to be given additional preferred stock whose going-concern value equals $\$ 1,364$. In face value terms, the old bondholders must be given additional preferred with a face value of $\$ 1,500: 78$ this is the measure of the bonus. Consequently, the old bondholders in the second case, in order to receive a payment of $\$ 95,000$ in cash equivalents, need to be given securities whose face value equals $\$ 101,500$, not $\$ 100,000$, as was the situation in the first case, where no qualitative shift took place. The $\$ 101,500$ face value payment is the same as resulted in the Section 11 example with an identical company; Stage Two, it is apparent, may be implemented by the Section 11 procedure. The two-stage process, with the second stage being a recapitalization carried out under the doctrines of Section 11 , results in the same payment outcome as does the second Chapter $\mathrm{X}$ example with the bonus rule. ${ }^{70}$

There is no need for courts to apply the bonus rule with imprecision or with haphazard irregularities caused by a lack of methodology. The congruence in function of the bonus rule and the investment value doctrine ${ }^{80}$ permits a congruence in application as well.

75. See Table I, Chart 6.

76. The going-concern value of the bonds used for payment is $\$ 50,000$, while the goingconcern value of the preferred stock is $48 / 55$ ths of $\$ 50,000$, or $\$ 43,636$. See Table I, Chart 9 .

77. See Table I, Charts 7,8.

78. $\$ 1,500$ is in the same ratio to the total face value of the preferred stock, $\$ 55,000$, as $\$ 1,364$ is to the total going-concern value of the preferred stock, $\$ 50,000$.

79. Both procedures-the current Chapter $\mathrm{X}$ process, and the two-stage process-respect, in the first instance, the use of contractual liquidation rights to measure claims and the use of reorganization value, along with face value, to measure payment. In Table I, compare Chart $\mathbf{3}$ with Chart 9.

80. See, e.g., Consolidated Rock Prods. Co. v. Dubois, 312 U.S. 510, 528-29 (1941) (rationale for bonus rule); Eastern Gas \& Fuel Associates, 30 S.E.C. 834, 914-15 (1950) (rationale for investment value doctrine). 